\title{
Spur Fruit Set Is Negatively Related with Current-year Spur Leaf Area in Almond
}

\author{
Sergio Tombesi \\ Dipartimento di Scienze Agrarie, Alimentari e Ambientali, Università degli \\ Studi di Perugia, Borgo 20 giugno 74, Perugia 06121, Italy
}

Bruce D. Lampinen ${ }^{1}$, Samuel Metcalf, and Theodore M. DeJong
Department of Plant Sciences University of California, One Shields Avenue,
Davis, CA 95616

Additional index words. absolute fruit set, almond, alternate bearing, spur fruit bearing, spur leaf area, relative fruit set

\begin{abstract}
Almond spurs are known to be the primary bearing unit in almond tree and are subject to alternate bearing. Fruits are a strong sink in bearing spurs and can influence spur leaf growth. At the same time the percent of flowers that set fruit on a spur (spur relative fruit set) could be influenced by the competition among multiple flowers/fruits borne on the same spur as well as by limited leaf area on the same spur. The aim of the present work was to investigate the relationship between current-year spur leaf area and spur absolute and relative fruit set. Approximately 2400 spurs were tagged and followed over 6 years and data concerning spur leaf area, number of flowers per spur, and number of fruits per spur were collected. Spur leaf area was reduced in fruiting spurs in comparison with non-fruiting spurs according to the number of fruits borne by each spur. This phenomenon contributes to spur alternate bearing because spur flowering and survival in the next year are a function of the leaf area in the current year. Relative fruit set in almond appears to be negatively associated with current-year spur leaf area. Competition among fruits on the same spur did not appear to influence spur relative fruit set.
\end{abstract}

Most perennial horticultural and forest tree species exhibit large annual fluctuations in fruit production that are often referred to as alternate bearing (Kelly and Sork, 2002; Monselise and Goldschmidt, 1982). In almond (Prunus dulcis Mill.), alternate bearing occurs at the spur level but not at the tree level, because only a fraction of the entire tree population of spurs bears fruits in a given year (Tombesi et al., 2011); however, it is still not clear why individual spurs alternate.

Different hypotheses on alternate bearing have been postulated for tree species. One hypothesis postulates that fruit and seeds are sources of hormones that may signal developing meristems to remain vegetative and not produce flowers for the year after a heavy fruit load (Chan and Cain, 1967; Hoad, 1978; Monselise and Goldschmidt, 1982). Some authors have specifically indicated that auxins (Hoad, 1978), gibberellins (Luckwill, 1970), or abscisic acid (Tamas et al., 1979) may be involved. However, hormones produced by seeds can also increase the sink strength of fruits and are not always linked to a direct inhibitory effect on the next year's flowering (Weinbaum et al., 2001).

Another hypothesis is that large fruit loads deplete carbohydrate and/or nutrient resources

Received for publication 6 Aug. 2014. Accepted for publication 5 Nov. 2014.

${ }^{1}$ To whom reprint requests should be addressed; e-mail bdlampinen@ucdavis.edu. that ultimately influence the development of floral buds. Kernels of pecans and pistachios are major assimilate sinks during the ripening process (Davis and Sparks, 1974; Spann et al., 2008) and depletion of carbohydrates (Rosecrance et al., 1998; Spann et al., 2008) and nutrients (Brown et al., 1995; Reidel et al., 2001) during the kernel fill period in nut crop species can negatively influence flower bud initiation, especially if kernel fill occurs simultaneously with the period of floral initiation. Floral initiation is reported to be strongly influenced by carbohydrate availability (Harley et al., 1942; Monselise and Goldschmidt, 1982; Reig et al., 2006).

In almond spurs (the main fruit bearing unit in almond trees), flower induction is related to the spur leaf area in the previous year and fruit bearing decreases the probability that a spur can bear flowers in the next year in comparison with spurs with similar leaf area that did not bear fruits in the previous year (Lampinen et al., 2011). Thus, fruit bearing appears to increase the amount of spur leaf area needed for flower induction, probably through depletion of carbohydrate reserves or through inhibition by fruit-associated hormones. Many studies have reported competition between reproductive activity and vegetative growth (i.e., shoot growth and/or leaf growth) when available resources are limited (Hasegawa et al., 2003; Kawamura and Takeda, 2006; Lovet Doust, 1989; Obeso, 2002; Reznik, 1985; Tuomi et al., 1983). Thus, on a spur basis, fruiting can compete not only with flower induction, but also with leaf growth. Furthermore, considering that almond spurs have a high degree of semiautonomy for carbohydrates (Heerema, 2005) and that in many species the percent of flowers on a spur that produce fruit (spur relative fruit set) is largely influenced by spur light exposure and spur leaf area (Stephenson, 1981), relative fruit set could be limited in spurs bearing a large number of flowers. The aim of the present work was to investigate the relationship between currentyear spur leaf area and spur absolute fruit set (number of nuts per spur) as well as spur relative fruit set (percent of flowers that set fruit).

\section{Materials and Methods}

A 59-ha orchard that was planted in 1996 and located in Kern County, CA, was chosen for the study. Tree spacing was $7.3 \mathrm{~m}$ between and $6.4 \mathrm{~m}$ within rows. Cultivar composition was $50 \%$ 'Nonpareil' with $25 \%$ 'Monterey' and $25 \%$ 'Wood Colony' as pollenizers [rows of 'Nonpareil' trees planted with alternating rows of the pollenizer cultivars to avoid pollen supply limitation (Dag et al., 2000)]. Spurs were tagged on 48 'Nonpareil' (blooms in midFebruary and is the most cultivated almond cultivar in California) trees randomly distributed across the orchard. A total of 2400 spurs were tagged with aluminium tags in late March and early Apr. 2001. The tags were placed on young spurs spanning from the most shaded portion of the canopy (near the trunk) to the more exposed, outer canopy positions at a height of $\approx 2$ to $3 \mathrm{~m}$. If tags were lost they were replaced at comparable locations to the original tags during the first 4 years of the study. Results reported in this study are based on data collected over 6 years (2002-07). The dynamics of annual leaf growth, flowering, fruitfulness, and spur mortality were quantified using annual assessments of tagged spurs (for more details on tagged spur populations, see Lampinen et al., 2011). In particular, for measuring spur leaf area, the following protocol was used: an adjacent, similar spur from a nearby location (but not so near as to be a direct influence on the tagged spur) with a similar light exposure was sampled for leaf area and specific leaf area analysis in July each year from 2001 to 2006 . In 2001, 2002, 2004 , and 2006, the adjacent spurs were sampled on all 48 trees, but in 2003 and 2005, these samples were only taken from eight of the 48 trees. Similar spurs were selected based on number and size of leaves, leaf length (visual comparison), and number of nuts present. Sampled leaves were wrapped in moist cloth and placed in a plastic bag and kept under refrigeration until leaf areas were measured. Leaf area was assessed by taking a digital photograph (Coolpix 900; Nikon, Tokyo, Japan) of all of the leaves on each adjacent sampled spur. Leaf areas for tagged spurs that did not have adjacent spurs sampled (2003 and 2005) for leaf area measurements were estimated by developing a regression equation relating the length of the longest leaf on each spur to the leaf area of spurs (using an independent sample of 400 spurs from a range 
of locations within the canopy). Sigmascan Pro (Systat Software Inc., San Jose, CA) image analysis software was used to count the number of leaves and calculate the leaf area for each spur from digital photographs. To assess the correlation between current-year spur leaf area and spur absolute fruit set in the current year, only spurs for which leaf area data were available (5195 spurs) were used for analysis (from 2002 to 2006). To assess the correlation between current-year spur leaf area and spur relative fruit set in the current year, only spurs that bore at least one flower were considered and for which leaf area data were available; thus, data of 1920 spurs were used for analysis (from 2002 to 2006). Retagged spurs were excluded in the studied sample. Spur relative fruit set was calculated as the number of fruits borne on each spur divided per the number of flowers borne on the same spur using a sample of 4354 spurs (those that bore at least one flower excluding retagged spurs from 2002 to 2007).

Statistical analysis was carried out using SAS (SAS statistical software; SAS Institute, Cary, NC). Means were analyzed by one-way analysis of variance (ANOVA) with significance level set at 0.05 . Means were then separated by Tukey's w-procedure at $P=0.05$. Regressions were performed by Sigmaplot 8.0 (Systat Software Inc., San Jose, CA) and $R^{2}$ significance was assessed by ANOVA.

\section{Results}

Total spur leaf area and number of leaves per spur in the current year varied in conjunction with the number of fruits borne per spur in the current year (Fig. 1). Spur leaf area of spurs that bore one, two, three, and four fruits was decreased by $15 \%, 59 \%, 68 \%$, and $84 \%$, respectively, compared with spurs that bore no fruits.

Current-year spur leaf area was negatively related to spur relative fruit set $\left(R^{2}=\right.$ $0.57, P<0.001$ ) (Fig. 2). Relative fruit set varied significantly among years $(P<0.001)$ but did not vary among spurs bearing different numbers of flowers $(P>0.05)$ (Fig. 3). Relative fruit set variation among years was between $18.4 \%$ in 2005 and $35.9 \%$ in 2004 . In 2003, 2004, 2005, and 2007 spur relative fruit set per spur appeared to be independent of the number of flowers borne by each spur; there was no statistical difference between the mean spur relative fruit set on spurs bearing variable numbers of flowers (Tukey test $P>$ 0.05). However, in 2002, spurs bearing five flowers had significantly $(P<0.05)$ lower relative fruit set than spurs bearing fewer numbers of flowers and in 2006, spurs with three flowers had the lowest relative fruit set.

\section{Discussion}

Developing fruits are strong resource sinks. In almond spurs, fruit bearing can be associated with spur death in the subsequent year (Lampinen et al., 2011). In this study, fruit bearing decreased spur leaf area and number of leaves per spur in the same year (Fig. 1).

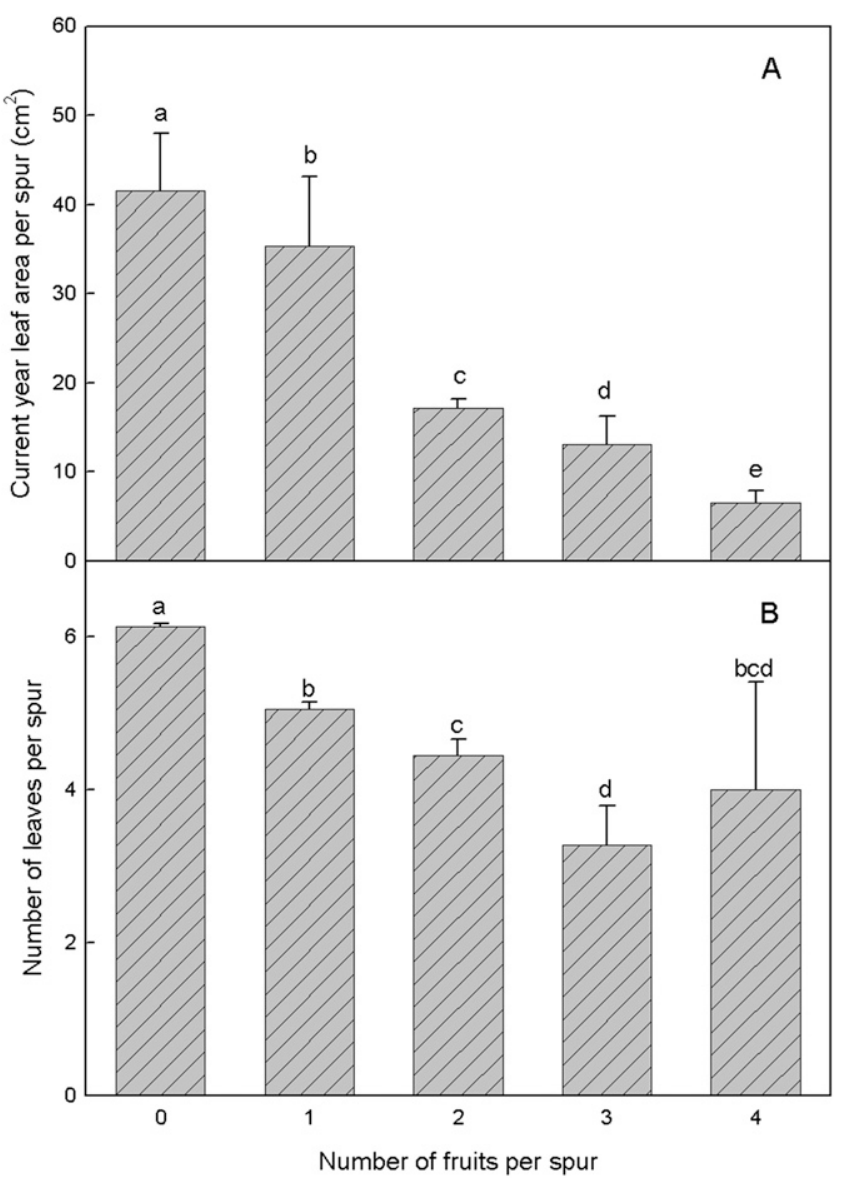

Fig. 1. Mean spur leaf area $\left(\mathrm{cm}^{2}\right)(\mathbf{A})$ and number of leaves per spur $(\mathbf{B})$ in flowering spurs with zero, one, two, three, and four fruits from 2002 to 2006 . Error bars represent $\operatorname{se}$ ( 0 fruit $\mathrm{n}=4424 ; 1$ fruit $\mathrm{n}=580 ; 2$ fruits $\mathrm{n}=158 ; 3$ fruits $\mathrm{n}=25 ; 4$ fruits $\mathrm{n}=8$ ). Bars with different letters are different at $P<0.05$ (Tukey's test).

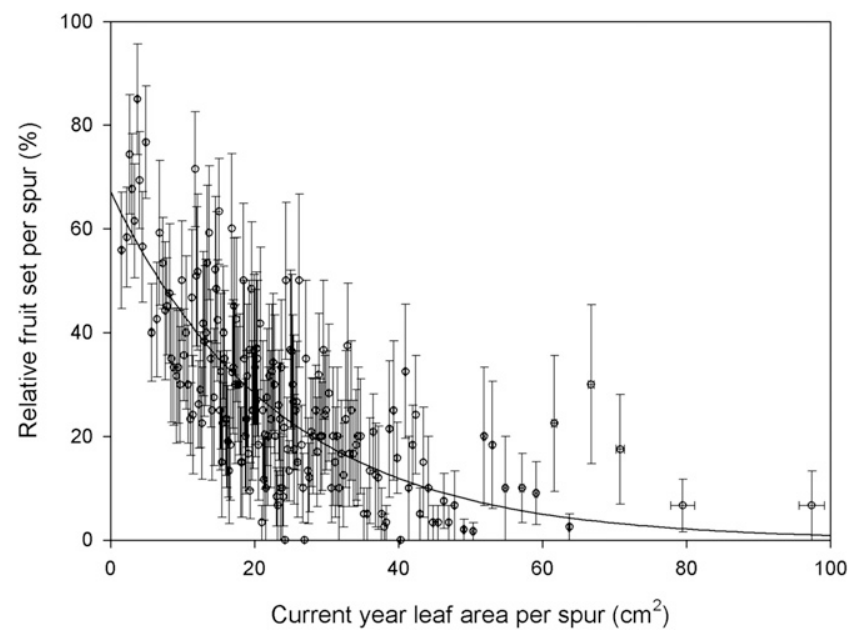

Fig. 2. Relationship between mean spur relative fruit set $(\%)$ and spur leaf area in the current year $\left(\mathrm{cm}^{2}\right)$ $\left(R^{2}=0.57, P<0.001\right)$. Each value is the mean of 10 spurs grouped by class of leaf area from 2002 to 2006. Error bars represent $\pm \mathrm{SE}$.

These data are consistent with those reviewed by Obeso (2002) on other tree species in which seed bearing decreased organ survival and/or vegetative growth. In horticultural tree species, the competition of vegetative growth with fruits is a well-known phenomenon (Minchin et al., 2010; Pavel and DeJong,
1993), but from a horticultural point of view, attention is often focused on the detrimental effects of vegetative growth on fruit development (Lopez and DeJong, 2007; McFadyen et al., 2011). Our results indicate that in fruit-bearing spurs, fruits not only interfere with flower induction processes to decrease 


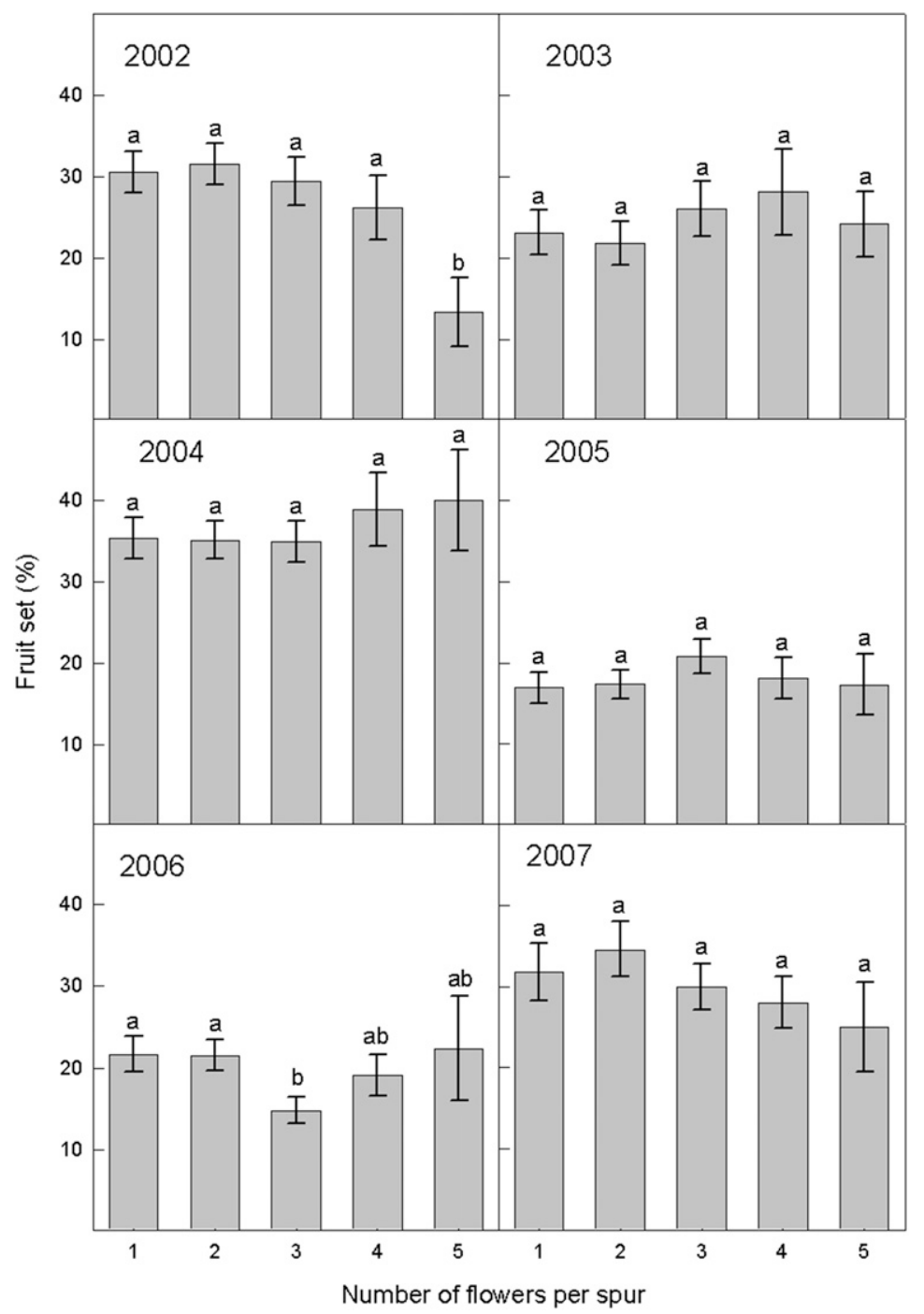

Fig. 3. Mean relative fruit set in spurs bearing one, two, three, four, and five flowers from 2002 to $2007 \pm \mathrm{SE}$. Bars with different letters are different at $P<0.05$ (Tukey's test).

spur flowering in the next year (Lampinen et al., 2011) and also compete with leaf development on the same spur in the same year. This competition may ultimately reduce probability of survival and return bloom because both return bloom and spur survival are linked to previous-year leaf area (Lampinen et al., 2011). An alternative explanation could be that one or more bioregulators produced by developing fruit are inhibitory to floral processes occurring in axillary buds and therefore result in no flowering the next year but are stimulatory to developmental processes associated with the vegetative state. However, the negative correlation between spur fruit number and spur leaf number and/or spur leaf area support the carbon limitation hypothesis. In this experiment, vegetative activity of fruiting spurs was decreased in comparison with non-fruiting spurs.

In other tree crops, fruit set is related to light exposure and current-year leaf area. In apple, spur fruit set is positively related to the number of leaves per spur (Proctor and Palmer, 1991) and light availability during the young fruitlet stage (Byers et al., 1991; Corelli Grappadelli et al., 1994). This implies that apple spur fruit set is dependent on currentseason carbon assimilation of adjacent spur leaves (Proctor and Palmer, 1991; Wünsche et al., 1996). A similar relationship has been reported in citrus (Iglesias et al., 2003). Thus, it may seem reasonable that in almond, spur leaf area in the current year would be positively correlated with spur fruit set in the same year. However, in our experiment with almond, there was a negative relationship between spur leaf area and fruit set in the current year.

An explanation for these contrasting behaviors likely resides in differences in the phenological development of the various species. With citrus (an evergreen species), flowers are borne on new shoots produced before flowering and new leaves are already present and functioning when flowers open (Iglesias et al., 2003). Similarly, apple flowers are borne terminally on spurs that grow vegetatively and functional leaves are produced before the time when flowers open (Fleckinger, 1948). With almond, flower buds are produced laterally on shoots or spurs, and the flower buds open before the production of new leaves borne on new terminal or lateral extensions of the shoot or spur (Felipe, 1977; Kester et al., 1996).
Therefore, with both citrus and apple, substantial new functional leaf area is present on the bearing unit before flowering, but, with almond, new functional leaf area develops after flowering. Furthermore, with both apple and citrus, flower buds and fruits grow on the current season's vegetative growth and currently active leaves either subtend (apple) or alternate with the flowers on the same axis (citrus). With almond spurs, flowers are borne laterally on previous-season growth and new leaves are produced on new terminal growth of the spur (Felipe, 1977). Thus, newly active leaves are distal rather than proximal (or in alternating positions) with the flowers and fruit.

These developmental differences between species may not only relate to their apparent differences in behavior with regard to spur leaf area and fruit set, but they are probably involved in the apparent competition between the number of fruits per spur and spur leaf area (Fig. 1). Because almond flower pollination occurs before significant leaf development, and fruits are attached in a proximal position relative to new leaves appearing on new growth at the distal end of spurs, the flowers and developing fruitlets probably have greater access to recently mobilized carbohydrates moving up from the lower parts of the tree during spring (Oliveira and Priestley, 1988). This may also involve earlier development of vascular tissue into flowers and fruitlets compared with new leaves as well as positional differences between the two types of organs (Westwood et al., 1967).

In apple, flower thinning has been reported to cause increases in relative fruit set (Martin et al., 1961; Quinlan and Preston, 1968). Similar results have been reported in almond (Socias I Company et al., 2004). However, in our experiments, relative fruit set per spur was negatively correlated with current-year spur leaf area (Fig. 2) and relative fruit set per spur was not correlated with the number of flowers borne on each spur (Fig. 3). These data suggest that very little competition for fruit set occurred among flowers borne on the same spur. These data are consistent with those reported by Kester and Griggs (1959) who described an overall decrease of absolute fruit set in response to deblossoming practices. Thus, spur alternate bearing appears to be primarily explained by the combined effects of the reduction of spur leaf area caused by fruit bearing and the fact that high rates of flowering and fruiting only occur on spurs with large amounts of leaf area per spur in the previous year (Lampinen et al., 2011). Thus, reduced leaf area in the bearing year is apparently not sufficient to support bud flower induction and contemporary fruit bearing. Finally, relative fruit set in almond did not appear to be influenced by currentyear spur leaf area or by competition among fruits on the same spur. However, these results cannot rule out a possible contribution of bioregulators to the inhibition of next year's flowering.

In conclusion, this research provides additional insight into the nature of spur semiautonomy in fruit bearing in tree species 
like almond. Although there is ample evidence that spurs function in a semiautonomous manner with respect to the potential of leaves of individual spurs to function as a source for carbohydrates affecting development of the next year's flower buds in the summer and fall (Heerema, 2005; Lampinen et al., 2011; Tombesi et al., 2011), the present research indicates that almond spurs are not semiautonomous with respect to supplying ample carbohydrates to support both fruit set and new leaf development in the spring. This behavior is clearly different from what has been reported for apple (Lauri et al., 1996; Proctor and Palmer, 1991) and citrus (Iglesias et al., 2003; Mehouachi et al., 2000). This study highlights the need to understand the importance of bearing habit and developmental details involving the proximity and timing of various organs on spurs when trying to understand how they function. It also provides greater insight into the relationship between fruit and foliage of alternate-bearing almond spurs. However, future studies on the relative importance of "competition" and "inhibition" are needed to further clarify spur alternate bearing in almond.

\section{Literature Cited}

Brown, P.H., S.A. Weinbaum, and G.A. Picchioni. 1995. Alternate bearing influences annual nutrient consumption and the total nutrient content of mature pistachio trees. Trees (Berl.) 9:158-164.

Byers, R.E., D.H. Carbaugh, C.N. Presley, and T.K. Wolf. 1991. The influence of light on apple fruit abscission. J. Hort. Sci. 66:7-17.

Chan, B.G. and J.C. Cain. 1967. The effect of seed formation on subsequent flowering. Proc. Amer. Soc. Hort. Sci 91:63-68.

Corelli Grappadelli, L., A.N. Lakso, and J.A. Flore. 1994. Early season patterns of carbohydrate partitioning in exposed and shaded apple branches. J. Amer. Soc. Hort. Sci. 119:596-603.

Dag, A., S.A. Weinbaum, R.W. Thorp, and D. Eisikowitch. 2000. Pollen dispensers (inserts) increase fruit set and yield in almonds under some commercial conditions. J. Apic. Res. 39:117-123.

Davis, J.T. and D. Sparks. 1974. Assimilation and translocation patterns of carbon 14 in the shoot of fruiting pecan trees Carya illinoensis Koch. J. Amer. Soc. Hort. Sci. 99:468-480.

Felipe, A.J. 1977. Almendro. Estados fenologicos. Informacion Tecnica Economica Agraria 27:8-9.

Fleckinger, J. 1948. Les stades vegétatifs des arbres fruitiers, en rapport avec le traitements. Pomologie Française Supplément:81-93.

Harley, C.P., J.R. Magness, M.P. Masure, L.A. Fletcher, and E.S. Degman. 1942. Investigation on the cause and control of biennial bearing in apple trees. USDA Tech. Bull 792. p. 1-58.

Hasegawa, S., K. Koba, I. Tayasu, H. Takeda, and H. Haga. 2003. Carbon autonomy of reproductive shoots of Siberian alder (Alnus hirsuta var sibirica). J. Plant Res. 116:183-188.

Heerema, R.J. 2005. Compartmentalization of carbon and nitrogen stresses within almond
[Prunus dulcis (Mill.) D.A. Webb] spurs. PhD diss., University of California, Davis, CA.

Hoad, G.V. 1978. The role of seed derived hormones in the control of flowering in apple. Acta Hort. 80:93-103.

Iglesias, D.J., F.R. Tadeo, E. Primo-Millo, and M. Talon. 2003. Fruit set dependence on carbohydrate availability in citrus trees. Tree Physiol. 23:199-204.

Kawamura, K. and H. Takeda. 2006. Cost and probability of flowering at the shoot level in relation to variability in shoot size within the crown of Vaccinium hirtum (Ericaceae). New Phytol. 171:69-80.

Kelly, D. and V.L. Sork. 2002. Mast seeding in perennial plants: Why, how, where? Annu. Rev. Ecol. Syst. 33:427-447.

Kester, D.E. and W.H. Griggs. 1959. Fruit setting in the almond: The effect of cross-pollinating various percentages of flower. Proc. Amer. Soc. Hort. Sci. 74:206-213.

Kester, D.E., G.C. Martin, and J.M. Labavitch. 1996. Growth and development, p. 90-97. In: Micke, W.C. (ed.). Almond production manual. Univ. of California Agric. and Nat. Resources, Berkeley, CA.

Lampinen, B.D., S. Tombesi, S. Metcalf, and T.M DeJong. 2011. Spur behaviour in almond trees: Relationships between previous year spur leaf area, fruit bearing and mortality. Tree Physiol. 31:700-706.

Lauri, P.E., E. Terouanne, and J.M. Lespinasse. 1996. Quantitative analysis of relationships between inflorescence size, bearing-axis size and fruit-set-an apple tree case study. Ann. Bot. (Lond.) 77:277-286.

Lopez, G. and T.M. DeJong. 2007. Spring temperatures have a major effect on early peach fruit growth. J. Hort. Sci. Biotechnol. 82:507-512.

Lovet Doust, J. 1989. Plant reproductive strategies and resource allocation. Trends Ecol. Evol. 4:230-234.

Luckwill, L.C. 1970. The control of growth and fruitfulness of apple trees, p. 237-254. In: Luckwill, L.C. and C.V. Cuttings (eds.). The physiology of tree crops. Academic Press, New York, NY.

Martin, D., T.L. Lewis, and J. Cerny. 1961. Jonathan spot-three factors related to incidence: Fruit size, break-down, and seed numbers. Austral. J. Agr. Res. 12:1039-1049.

McFadyen, L.M., D. Robertson, M. Sedgley, P. Kristiansenn, and T. Olesen. 2011. Postpruning shoot growth increases fruit abscission and reduces stem carbohydrates and yield in macadamia. Ann. Bot. (Lond.) 107:993-1001.

Mehouachi, J., D.J. Iglesias, F.R. Tadeo, M. Agusti, E. Primo-Millo, and M. Talon. 2000. The role of leaves in citrus fruitlet abscission: Effects on endogenous gibberellins levels and carbohydrate content. J. Hort. Sci. Biotechnol. 75:79-85.

Minchin, P.E.H., W.P. Snelgar, and A.J. Blattmann Hall. 2010. Competition between fruit and vegetative growth in Hayward kiwifruit. N. Z. J. Crop Hort. Sci. 38:101-112.

Monselise, S.P. and E.E. Goldschmidt. 1982. Alternate bearing in fruit trees. Hort. Rev. 4:128-173.

Obeso, J.R. 2002. The costs of reproduction in plants. New Phytol. 155:321-348.
Oliveira, C.M. and C.A. Priestley. 1988. Carbohydrate reserves in deciduous fruit trees. Hort. Rev. 10:403-430.

Pavel, E.W. and T.M. DeJong. 1993. Source- and sink-limited growth periods of developing peach fruits indicated by relative growth rate analysis. J. Amer. Soc. Hort. Sci. 118:820-824.

Proctor, J.T.A. and J.W. Palmer. 1991. The role of spur and bourse leaves of three apple cultivars on fruit set and growth and calcium content. J. Hort. Sci. 66:275-282.

Quinlan, J.D. and A.P. Preston. 1968. Effects of thinning blossoms and fruitlets on growth and cropping of sunset apple. J. Hort. Sci. 43:373381.

Reidel, E.J., P.H. Brown, R.A. Duncan, and S.A. Weinbaum. 2001. Almond productivity as related to tissue potassium. Better Crops 85:21-23.

Reig, C., D. Gonzalez-Rossia, M. Juan, and M. Agusti. 2006. Effects of fruit load on flower bud initiation and development in peach. J. Hort. Sci. Biotechnol. 81:1079-1085.

Reznik, D. 1985. Costs of reproduction: An evaluation of the empirical evidence. Oikos 44:257-267.

Rosecrance, R.C., S.A. Weinbaum, and P.H. Brown. 1998. Alternate bearing affects nitrogen, phosphorus, potassium and starch storage pools in mature pistachio trees. Ann. Bot. (Lond.) 82:463-470.

Socias I Company, R., J.M. Alonso, and J. Gòmez Aparisi. 2004. Fruit set and productivity in almond as related to self-compatibility, flower morphology and bud density. J. Hort. Sci. Biotechnol. 79:754-758.

Sokal, R.R. and F.J. Rohlf. 1969. Biometry. 1st Ed. W.H. Freeman and Co., San Francisco, CA.

Spann, T.M., R.H. Beede, and T.M. DeJong. 2008 Seasonal carbohydrate storage and mobilization in bearing and non-bearing pistachio (Pistacia vera) trees. Tree Physiol. 28:207-213.

Stephenson, A.G. 1981. Flower and fruit abortion: Proximate causes and ultimate functions. Annu. Rev. Ecol. Syst. 12:253-279.

Tamas, I.A., D.H. Wallace, P.M. Lundorf, and J.L. Ozbun. 1979. Effects of older fruits on abortion and abscissic acid concentration of younger fruit in Phaseulus vulgaris L. Plant Physiol. 64:620-622.

Tombesi, S., B.D. Lampinen, S. Metcalf, and T.M. DeJong. 2011. Relationship between spur- and orchard-level fruit bearing in almond (Prunus dulcis). Tree Physiol. 31:1413-1421.

Tuomi, J., T. Hakala, and E. Haukioja. 1983. Alternative concepts of reproductive effort, costs of reproduction, and selection in lifehistory evolution. Amer. Zool. 23:25-34.

Weinbaum, S.A., T.M. DeJong, and J. Maki. 2001 Reassessment of seed influence on return bloom and fruit growth in 'Bartlett' pear. HortScience 36:295-297.

Westwood, M.N., L.P. Batjer, and H.D. Billingsley. 1967. Cell size, cell number and fruit density of apples as related to fruit size, position in the cluster and thinning method. Proc. Amer. Soc. Hort. Sci. 91:51-62.

Wünsche, J.N., A.N. Lakso, T.L. Robinson, F. Lenz, and S.S. Denning. 1996. The bases of productivity in apple production systems: The role of light interception by different shoot types. J. Amer. Soc. Hort. Sci. 121:886-893. 